\title{
Keanekaragaman Serangga pada Bunga Tomat (Lycopersicon esculentum Mill.) di Lahan Pertanian Organik
}

\author{
MOSI RETNANI FAJARWATI, TRI ATMOWIDI, DAN DORLY \\ Departmen Biologi, Fakultas Matematika dan Ilmu Pengetahuan Alam \\ Institut Pertanian Bogor
}

(diterima Juni 2009, disetujui Agustus 2009)

\begin{abstract}
Insect Diversity On Tomato Flowers (Lycopersicon esculentum Mill.) in Organic Agriculture. Study on the diversity of insect visitors on tomato flowers were conducted at Bina Sarana Bakti (BSB) organic farm, Cisarua, West Java. Diversity of insects were observed by observational method, an $10 \mathrm{~m}^{2}$ area of tomato plants in the morning, mid-day, and afternoon. Observations were conducted during 20 days. Diversity of visiting insects were analyzed by Shannon diversity and its evenness. Similarity of visiting insects between time of observations were analyzed by Jaccard similarity index. In organic farm, insect visitors of tomato plants consist of six orders belonging to eight species. Insect visitors of tomato flowers were dominated by Thrips sp. (Thysanoptera) and Hylaeus sp. (Hymenoptera). Hylaeus sp. was a main pollinator of tomato plants. Diversity of insect visitors in the morning and mid-day was higher than in the afternoon. Evenness of insect visitors of tomato flowers between observation times were relatively equal.
\end{abstract}

KEYWORDS: Diversity, insect visitors, tomato, organic farm.

\section{PENDAHULUAN}

Interaksi antara serangga dengan tanaman berbunga diperkirakan telah terjadi sejak era Cretaceous (130-90 juta tahun yang lalu) (Schoonhoven et al. 1998). Interaksi antara tanaman dan serangga mendapat keuntungan berupa serbuksari dan nektar sebagai sumber pakan, tempat berlindung, dan tempat berkembang biak (Sedgley \& Griffin 1989). Bagi tumbuhan, interaksi dengan serangga memberi keuntungan, yaitu terjadinya penyerbukan yang merupakan bertemunya serbuksari de- ngan kepala putik (Sedgley \& Griffin 1989; Kevan 1984).

Di alam, serangga membantu penyerbukan sekitar dua per tiga dari total tanaman berbunga dan sekitar 400 spesies tanaman pertanian (Schoonhoven et al. 1998; Delaplane \& Mayer 2000). Serangga yang berperan dalam penyerbukan tanaman adalah kumbang, lalat, lebah, tawon, gonteng (ordo Hymenoptera), kupu-kupu dan ngengat. Diantara serangga tersebut, lebah yang memiliki sekitar 20.000 spesies, merupakan agens penyerbuk paling penting (Gulland \& Cranston 
2000). Raw (2000) melaporkan bahwa pada tanaman cabe (Capsicum annuum), keragaman spesies serangga yang mengunjungi bunga tanaman tersebut berkaitan dengan sumberdaya yang tersedia, jumlah bunga, jarak antar tanaman, dan jarak pencarian pakan (foraging distance).

Tanaman tomat (Lycopersicon esculentum Mill.) merupakan tanaman berumah satu (monoecious) dan umumnya menyerbuk sendiri. Bunga bersifat unisexual, yaitu ditemukan putik dan stamen dalam satu bunga. Diameter bunga sekitar $2 \mathrm{~cm}$, mahkota bunga (petal) berwarna kuning, berjumlah 6 petal dan saling berlekatan di bagian dasar bunga. Kelopak bunga berwarna hijau membentuk tabung pendek. Benangsari (stamen) berwarna kuning muda, berjumlah 6 dan bersatu di bagian kepalasari (anther) membentuk kerucut (conus) yang mengelilingi putik. Tangkai putik bisa lebih pendek atau lebih tinggi dari kerucut benangsari, tergantung varietas. Masa reseptive kepala putik (stigma) terjadi 1-2 hari sebelum anthesis, sampai 4-8 hari setelah anthesis. Dengan struktur kepala sari yang membentuk kerucut, maka untuk melepaskan serbuksari dari kepala sari diperlukan getaran (vibrasi) dan penyerbukan sendiri umumnya terjadi pada tanaman ini. Bunga tanaman ini tidak atau sedikit menghasilkan nektar. Di alam, penyerbukan silang tanaman tomat terjadi sangat rendah $(0,07-12 \%)$ dan umumnya terjadi pada varietas dengan tangkai putik yang panjang dan kepala putik yang terbuka (Delaplane \& Mayer 2000). Di Eropa, bumble bee (Hymenoptera) merupakan penyerbuk potensial tanaman tomat karena mampu menggetarkan kerucut benangsari (King \& Buchmann 1996). Penyerbukan tanaman tomat oleh bumble bees menghasilkan bobot buah, diameter dan jumlah biji yang lebih besar dibandingkan bila tanpa bumble bee (Dogterom et al. 1998).

Pertanian organik Bina Sarana Bakti (BSB) terletak di Kecamatan Cisarua, Bogor, Jawa Barat, berada pada ketinggian 800-1.100 m dpl (diatas permukaan laut). dengan tingkat kemiringan lokasi 3-5\%, dan beriklim tropik basah. Di sebelah utara, lahan pertanian tersebut berbatasan dengan persawahan dan di sebelah Timur, Barat, dan Selatan berbatasan dengan pemukiman penduduk (Paembonan 2003). Pertanian organik tersebut memiliki lahan seluas \pm 6 ha, yang terbagi menjadi 10 blok dan ditanam sekitar 50 spesies sayuran, diantaranya tomat, wortel, bawang daun, caesin dan kacang-kacangan Penelitian ini bertujuan mempelajari keragaman spesies serangga yang mengunjungi bunga tanaman tomat di lahan pertanian organik BSB.

\section{BAHAN DAN METODE}

\section{Waktu dan Tempat}

Penelitian dilakukan di Kebun pertanian Organik BSB pada bulan Mei 
2004-Januari 2005. Identifikasi spesimen serangga dilakukan di Bagian Biosistematik dan Ekologi Hewan, Departemen Biologi, FMIPA dan di Laboratorium Biosistematika Serangga, Departemen Proteksi Tanaman, Fakultas Pertanian, IPB. Verifikasi spesimen serangga dilakukan di Laboratorium Entomologi, Bidang Zoologi, Pusat Penelitian Biologi-LIPI, Cibinong, Jawa Barat.

\section{Pengamatan Keanekaragaman Serangga Pengunjung}

Pengamatan keragaman serangga pengunjung bunga tomat dilakukan pada lahan pertanaman seluas $10 \mathrm{~m}^{2}$. Pengamatan serangga dilakukan dalam tiga periode waktu, yaitu pagi (pukul 07.00-09.00), siang (10.00-12.00), dan sore hari (13.00-15.00). Pada setiap periode waktu, dilakukan pengamatan serangga pengunjung pada satu tanaman, sehingga tanaman yang digunakan untuk pengamatan berbeda dari satu periode ke periode berikutnya. Pengamatan serangga pengunjung dilakukan hanya pada saat cuaca cerah dengan total pengamatan selama 20 hari. Metode yang digunakan dalam pengamatan serangga ialah scan sampling (Martin \& Bateson 1993), yaitu menghitung jumlah spesies dan individu serangga pengunjung. Serangga belum di ketahui namanya pada saat pengamatan, ditangkap dengan sweep net untuk keperluan identifikasi.

\section{Pengawetan dan Identifikasi Spesimen Serangga}

Serangga yang dikoleksi yang berukuran relatif besar, diawetkan secara kering. Pengawetan secara kering dilakukan dengan memasukkan spesimen ke dalam oven pada suhu $37^{\circ} \mathrm{C}$ selama tujuh hari. Sedangkan spesimen yang kecil (Diptera, Thysanoptera, dan Homoptera) diawetkan secara basah dalam ethanol 70\% (Borror et al. 1996). Identifikasi spesimen berdasarkan Borror et al. (1996), Lewis (1973), McAlpine (1981), dan Michener (2000).

\section{Analisis Data}

Data tentang serangga pengunjung bunga tomat dihitung rata-rata dan persentase per periode waktu dan dihitung indeks keaneka-ragamannya dengan menggunakan indeks keragaman dan kemerataan Shannon (H'dan E). Kesamaan serangga pengunjung antar periode pengamatan (pagi, siang, dan sore) dihitung dengan indeks kesamaan Jaccard (Cj) (Magurran 1987). Rumus yang di gunakan adalah:

$$
\begin{aligned}
& \mathrm{H}^{\prime}=-\sum \mathrm{n}_{\mathrm{i}} / \mathrm{N} \ln \mathrm{n}_{\mathrm{i}} / \mathrm{N} \\
& \mathrm{E}=\mathrm{H}^{\prime} / \ln \mathrm{S} \\
& \mathrm{Cj}=\mathrm{j} /(\mathrm{a}+\mathrm{b}-\mathrm{j})
\end{aligned}
$$

Keterangan: $n_{i}=$ jumlah individu dari i spesies; $\mathrm{N}=$ jumlah total individu; $\mathrm{S}=$ jumlah spesies; $\mathrm{J}=$ jumlah spesies yang ditemukan pada waktu a dan b; $\mathrm{a}=$ jumlah spesies yang ditemukan pada waktu $a ; b=$ jumlah spesies yang ditemukan pada waktu b. 


\section{HASIL DAN PEMBAHASAN}

\section{Keanekaragaman Serangga \\ Pengunjung}

Hasil pengamatan didapatkan delapan spesies serangga pengunjung bunga tomat, yang termasuk dalam enam ordo. Keenam ordo tersebut ialah Hymenoptera, Diptera, Lepidoptera, Thysanoptera, Hemiptera, dan Homoptera. Empat spesies yang ditemukan dominan, yaitu Thrips sp. (32,32\%), Hylaeus sp. (23\%), Macrolophus sp. (18,25\%) dan Aphis fabae (17,59\%), sedangkan empat spesies serangga lainnya memiliki kunjungan rendah (kurang dari 5\%). Berdasarkan waktu pengamatan, keragaman serangga pada bunga tomat di pagi dan siang hari $\left(\mathrm{N}=11 ; 03 ; \quad \mathrm{S}=7 ; \quad \mathrm{H}^{\prime}=1,61 \quad\right.$ dan $\left.\mathrm{N}=10,85 ; \mathrm{S}=8 ; \mathrm{H}^{\prime}=1,67\right)$ lebih tinggi dibandingkan sore hari $(\mathrm{N}=3,23 ; \mathrm{S}=7$; $\mathrm{H}^{\prime}=1,56$ ). Kemerataan (evenness) serangga pengunjung bunga tomat di pagi, siang, dan sore hari relatif sama $(E=0,80-0,83) \quad$ (Tabel 1). Jumlah spesies yang ditemukan di pagi, siang, dan sore hari tidak jauh berbeda, yaitu masing-masing 7, 8, dan 7 spesies. Kesamaan spesies yang berkunjung di pagi-siang dan siang-sore mencapai $87,5 \%$. Kesamaan spesies yang ditemukan pagi dengan sore hari lebih rendah (75\%) (Tabel 2). Data lingkungan yang diamati ialah rata-rata curah hujan (Mei-Juni) 4,46 mm/hari, suhu harian berkisar $14-26^{\circ} \mathrm{C}$, dan kelembaban udara $81,4 \%$.

Pada pertanaman tomat di BSB diamati enam ordo serangga, yang termasuk dalam delapan spesies. Berdasarkan peranannya, serangga pengunjung bunga tomat dapat dikelompokkan sebagai predator (Macrolophus sp.), hama (Thrips sp., Aphis fabae, Drosophila sp., Tipula sp., dan Dipteral sp.1), dan penyerbuk (Hylaeus sp., Amata sp.). Berdasarkan kelimpahannya, maka Thrips sp. $(32,32 \%)$ merupakan spesies yang paling dominan ditemukan pada bunga tomat, diikuti oleh Hylaeus sp. (23\%), Macrolophus sp. (18,25\%), dan Aphis fabae (17,59\%). Aktivitas kunjungan serangga, umumnya pada pagi sampai siang hari dan aktivitas kunjungan di sore hari semakin menurun.

Beberapa faktor yang mempengaruhi kunjungan serangga pada bunga, diantaranya adalah kandungan nektar, konsentrasi gula, kandungan senyawa kimia (Martin \& McGregor 1973), dan kelimpahan bunga (Kandori 2002; Hegland \& Todland 2005). Pada bunga tomat, sedikitnya jumlah spesies (8 spesies) dan individu serangga yang berkunjung berkaitan dengan morfologi bunga, serbuksari yang tersembunyi di dalam kerucut benang sari, dan kandungan nektar yang tidak ada atau sangat sedikit (Cribb, 1990). 
Tabel 1. Jumlah individu, spesies, dan indeks keragaman serangga pengunjung bunga tomat (L. esculentum Mill.)

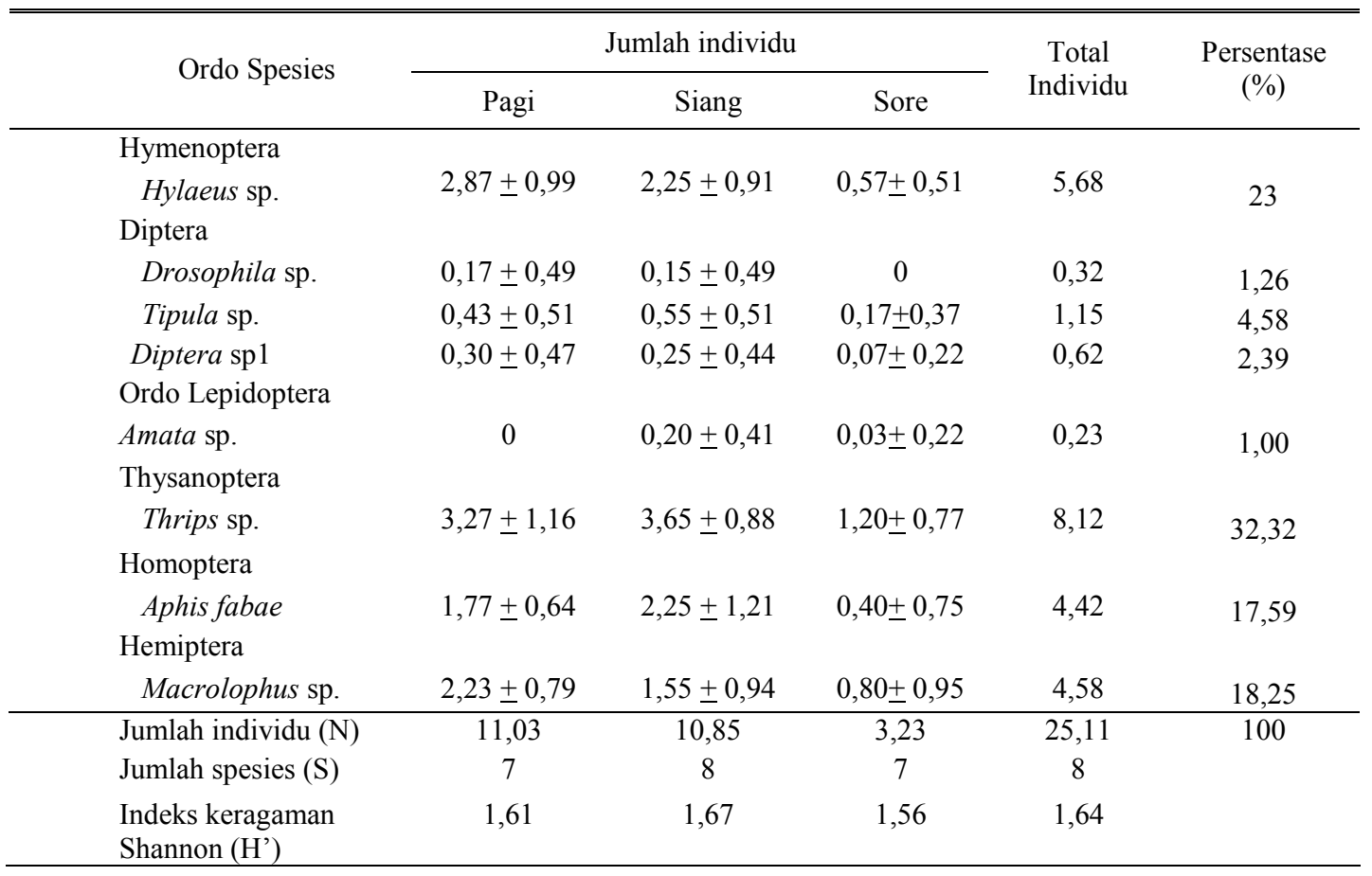

Tabel 2. Indeks kesamaan Jaccard serangga pengunjung bunga tomat

\begin{tabular}{cccc}
\hline \hline Waktu & Pagi & Siang & Sore \\
& $(07.00-09.00 \mathrm{WIB})$ & $(10.00-12.00 \mathrm{WIB})$ & $(13.00-15.00 \mathrm{WIB})$ \\
\hline Pagi & 1 & & \\
$(07.00-09.00)$ & & & \\
Siang & 0,875 & 1 & 1 \\
$(10.00-12.00)$ & 0,750 & 0,875 & \\
Sore & & & \\
$(13.00-15.00)$ & &
\end{tabular}

Keanekaragaman serangga pengunjung bunga tomat di pagi dan siang hari lebih tinggi dibandingkan sore hari. Keragaman serangga yang tinggi di pagi hari juga dilaporkan oleh Atmowidi et al. (2007) pada tanaman caisin (Brassica rapa), yaitu puncak kunjungan terjadi pada pukul 08.30 dan 09.30.
Keragaman serangga berkaitan dengan melimpahnya sumberdaya tanaman, terutama serbuk sari dan nektar. Bagi serangga, serbuksari digunakan sebagai sumber protein, sedangkan nektar sebagai sumber gula yang sangat dibutuhkan untuk kehidupannya (Plowright et al. 1993). Kombinasi gula dalam nektar menentukan keanekaragaman serangga yang mengun- 
jungi (Hainsworth \& Hamill, 1993). Selain serbuksari dan nektar, morfology bunga berpengaruh terhadap keanekaragaman serangga pengunjungnya (Neal et al. 1998). Keragaman serangga tinggi pada tanaman dengan bunga yang serbuksari dan nektarnya terbuka dan mudah diakses oleh serangga (Sedgley \& Griffin 1989). Atmowidi et al. (2007) melaporkan bahwa pada tanaman caisin (B. rapa) keanekaragaman serangga penyerbuk berkaitan dengan kelimpahan bunga. Hal yang sama juga dilaporkan oleh Hegland \& Todland (2005) bahwa keragaman lebah penyerbuk $A$. mellifera sangat tinggi pada saat musim pembungaan tanaman Erythronium umbilicatum. Pada saat pembungaan, lebah akan mendapatkan sumberdaya lebih banyak dalam waktu yang singkat (Westphal et al. 2006).

Thrips sp. (Thysanoptera) merupakan pengunjung dominan pada bunga tanaman tomat. Thrips sp. memiliki ukuran tubuh yang kecil (0,5-14 mm). Pengamatan pada bunga tanaman tomat, thrips banyak melakukan aktivitas di mahkota bunga dan keluar masuk kerucut benangsari. Lewis (1973) melaporkan T. tabacci mampu membawa 137 butir serbuksari pada tanaman gula "bit" (Beta vulgaris). Pada tanaman bawang, thrips Frankliniella occidentalis mampu masuk ke dalam kuncup bunga sehingga menyebabkan penyerbukan berlangsung lebih awal. Pada tanaman kelapa sawit di Indonesia dan Malaysia, Thrips hawaiinensis Morgan dilaporkan membantu penyerbukan. Tidak menutup kemungkinan bahwa thrips ini juga membantu penyerbukan tanaman tomat. Diperlukan pengamatan lebih lanjut untuk mengetahui peranan thrips dalam penyerbukan tanaman tomat, karena pada umumnya Thrips dikenal sebagai hama pada tanaman pertanian dan perkebunan (Lewis 1973).

Lebah yang ditemukan mengunjungi bunga tomat adalah lebah soliter Hylaeus sp. Pada saat mengunjungi bunga tomat, lebah tersebut mampu menggetarkan kerucut benangsari, sehingga serbuksari jatuh di kepala putik. Lebah Hylaeus diamati membawa serbuksari di tungkai belakangnya. Kemampuan lebah Hylaeus sp. dalam menggetarkan kerucut benangsari tersebut menjadikan Hylaeus sebagai penyerbuk pada tanaman tomat. Kemungkinan besar lebah tersebut berperan dalam penyerbukan silang tanaman tomat. Lebah Hylaeus juga dilaporkan mengunjungi bunga tanaman caisin di daerah pinggiran hutan Taman Nasional Gunung Halimun, Jawa Barat (Atmowidi et al. 2007). Delaplane \& Mayer (2000) juga melaporkan bahwa beberapa spesies lebah lokal (native bees) berperan dalam penyerbukan tanaman tomat di daerah tropis. Di daerah subtropis, penyerbuk utama tanaman tomat ialah Bombus spp. (Pulumbo et al. 1996; Morandin et al. 2001). 
Serangga lain yang ditemukan pada bunga tomat ialah kepik predator $M a$ crolophus sp. (Hemiptera) (Goula et al. 2002). Pengamatan pada bunga tomat, kepik tersebut berjalan, sesekali berhenti di mahkota bunga, kerucut benangsari, dan kelopak bunga. Disamping itu, bunga tomat juga dikunjungi oleh Aphis fabae (Homoptera) yang umumnya berperan sebagai hama tanaman. Ngengat Amata sp. yang ditemukan pada bunga tomat berbeda dengan ngengat pada umumnya, ngengat ini aktif di siang hari (Holloway 1988). Amata sp. Yang berkunjung populasinya sedikit sehingga kurang berpengaruh dalam penyerbukan. Hal tersebut berhubungan dengan ketersediaan nectar yang sedikit. Ada tiga spesies lalat (Diptera) ditemukan pada bunga tomat, yaitu Drosophila sp., Tipula sp., dan satu spesies yang tidak teridentifikasi. Lalat Drosophila sp. dikenal sebagai lalat buah, sedangkan Tipula sp. sebagai hama tanaman (McAlpine 1981). Keragaman serangga pengunjung bunga tomat dapat bervariasi pada setiap wilayah. Hal tersebut dipengaruhi oleh perbedaan suhu, iklim, kondisi geografis, dan vegetasi sehingga setiap wilayah mempengaruhi kekhasan spesies (Romoser 1973; Speight et al. 1999).

\section{KESIMPULAN}

Pengamatan pada bunga tanaman tomat di lahan pertanian organik BSB didapatkan empat spesies yang dominan, yaitu Thrips sp. (Thysanoptera), Hylaeus sp. (Hymenoptera), Aphis fabae (Homoptera), dan Macrolophus sp. (Hemiptera). Lebah Hylaeus sp. membantu penyerbukan tanaman tomat dengan cara menggetarkan kerucut benangsari. Keragaman serangga pengunjung pada tanaman tomat tinggi di pagi dan siang hari, sedangkan di sore hari keragamannya lebih rendah. Kemampuan Thrips dalam penyerbukan tanaman tomat perlu diteliti lebih lanjut.

\section{UCAPAN TERIMA KASIH}

Penulis mengucapkan terima kasih kepada Dra. Dewi Sartiami, M.Si. di Departemen Proteksi Tanaman, Faperta IPB dan Dr. Sih Kahono di Museum Zoologi, Pusat Penelitian Biologi-LIPI atas bantuan identifikasi spesimen. Kepada Yayasan Bina Sarana Bakti atas ijin dalam penggunaan lahan untuk pelaksanaan penelitian.

\section{DAFTAR PUSTAKA}

Atmowidi T, Buchori D, Manuwoto S, Suryobroto B, Hidayat P. 2007. Diversity of insect pollinators and seed set of mustard (Brassica rapa: Brassicaceae). Hayati 14:155-161.

Borror DJ, Triplehorn CA, Johnson NF. 1996. Pengenalan Pelajaran Serangga Ed. ke-6. Yogyakarta: Gadjah Mada University Press.

Cribb D. 1990. Pollination of tomato crops by honey bees. Bee Craft 
172: 228-231

Delaplane KS, Mayer DF. 2000. Crop Pollination by Bees. New York: CABI Publishing.

Dogterom MH, Matteoni JA, Flowright BC. 1998. Pollination of greenhouse tomatoes by the North American Bombus vosnesenskii (Hymenoptera: Apidae). J. Econ. Entomol. 91:71-75.

Goula M, Alomar O, Castane C. 2002. Predatory Mirids in Tomato Crops. Norwich: European Whitefly Studies Network (EWSN). http: //www.whitefly.org [11 Januari 2005]

Gulland PJ, Cranston PS. 2000. The Insect : An Outline of Entomology $2^{\text {nd }}$ Ed. USA: Blackwell Science Ltd.

Hainsworth FR, Hamill T. 1993. Foraging rules for nectar: food choices by painted ladies. Am Nat 142: 857-867.

Hegland SJ, Totland O. 2005. Relationships between species floral traits and pollinator visitation in a temperate grassland. Oecologia 145: 586-594.

Kandori I. 2002. Diverse visitors with various pollinator importance and temporal change in the important pollinators of Geranium thunbergii (Geraniaceae). Ecol. Research 17:283-294.

Kevan PG. 1984. Bee Botany: Pollination, foraging and floral calendars. Proceedings of the Expert Consultation on Beekeeping in Apis mellifera in Tropical and SubTropical Asia. Food and Agricultural Organization of the United States, Rome. Pp. 51-56.
King MJ, Buchmann SL. 1996. Sonocation dispensing of pollen from Solanum laciniatum flow-ers. Functional Ecology 10: 449-456.

Lewis T. 1973. Thrips, Their Biology, Ecology and Economic Importance. London: Academic Press Inc. ltd.

Magurran AE. 1987. Ecological Diversity and Its Measurement. New Jersey: Princeton University Press.

Martin EC, McGregor SE. 1973. Changing trend in insect pollination of commercial crops. Am. Rev. Entomol.18: 207-226.

Martin P, Bateson P. 1993. Measuring Behaviour: An Introductory Guide. $2^{\text {nd }}$ Ed. Cambrige: Cambrige Univ. Press.

McAlpine et al. 1981. Manual of Nearctic Diptera vol 1-2. Canada: Canadian Government Publishing Centre.

Michener CD. 2000. The Bees of The World. Baltimore: The Johns Hopkins University Press.

Morandin LA, Laverty TM, Kevan PG. 2001. Effect of bumble bee (Hymenoptera: Apidae) polliantion intensity on the quality of greenhouse tommatoes. J. Econ. Entomol. 94:172-179.

Neal P, Dafni A, Giurfa M. 1998. Floral symmetry and its role in plant-pollinator systems: terminology, distribution and hypotheses. Ana. Rev. Ecol. Syst. 29: 345373.

Paembonan A. 2003. Budidaya tomat di pertanian organik Yayasan Bina Sarana Bakti Cisarua Laporan Praktik Lapangan. Bogor: Institut Pertanian Bogor. 
Plowright RC, Thomson JD, Lefkovitch LP, Plowright CMS. 1993. An experimental study of the effect of colony resource level manipulation on foraging for pollen by worker bumble bees. Canad. J. Zool. 71: 1393-1396.

Pulumbo AD et al. 1996. Effects of bumble bees on tommato cultivation. Culture Protete 25:61-65.

Raw A. 2000. Foraging behaviour of wild bees at hot pepper flowers (Capsicum annuum) and its possible influence on cross pollination. Ann. Bot. 85: 487-492.

Romoser WS. 1973. The Science of Entomology. New York: MacMillan Publishing.
Schoonhoven LM, Jermy T, van Loon JA. 1998. Insect-Plant Biology: from physiology to evolution. London: Chapman \& Hall.

Sedgley M, Griffin AR. 1989. Sexual Reproduction of Tree Crops. London: Academic Press.

Speight MR, Hunter MD, Watt AD. 1999. Ecology of InsectsConcepts and Applications. London: Blackwell Science Ltd.

Wesphal C, Steffan-Dewenter I, Tscharntke T. 2006. Foraging trip duration of bumblebees in relation to landscape-wide resource availability. Econ. Entomol. 31: 389394. 